\title{
Tunnel Portal Construction using Sequential Excavation Method: A Case Study
}

\author{
Rana Muhammad Asad $\mathrm{Khan}^{1 *}$, Zaka Emad ${ }^{2}$ and ByungWan $\mathrm{Jo}^{1}$ \\ ${ }^{1}$ Department of Civil and Environmental Engineering, \\ Hanyang University, \\ Seoul, South Korea. \\ ${ }^{2}$ Department of Mining Engineering, \\ University of Engineering and Technology, \\ Lahore, Pakistan.
}

\begin{abstract}
Portal excavation in soft rock is one of the most challenging tasks in the construction of underground facilities. Significant convergence, collapses and surface settlement are usually associated with portal construction. Alluvium is loose unconsolidated material and most often tunnels constructed through tend to destabilize. In this study, portal excavation design has been analyzed using the finite element based computer program known as Phase2. The method of top heading and benching was not a suitable approach, keeping in view the previous experience. Subsequently, a different design of sequential excavation method (SEM) was proposed. Minimum convergence, minimum surface settlement, and machinery constraints were considered to be the vital importance for selection of final design. The results of finite element method (FEM) analysis showed that the finally selected SEM design has a roof convergence of $4 \mathrm{~mm}$ for the heading and full face excavation has $25 \mathrm{~mm}$. These values were comparable with the ones obtained from a 5-pin convergence station, installed during the portal excavation $(0.5 \mathrm{~m}$ inside from the portal). No or very little surface settlement was shown by the numerical model and actual field observation. Consequently, a proper SEM design based on numerical modeling allowed a successful construction of a large portal in alluvial deposits.
\end{abstract}

Keywords: Tunnel; portal; numerical modeling; finite element method; sequential excavation method

\footnotetext{
*Corresponding Email: masadkhan87@gmail.com
} 


\section{INTRODUCTION}

Underground structures have significant importance for the economy of a country. The stability of such structure is of extreme importance because the safety of human lives is directly associated. Excavation of an underground opening always induces some deformation and stresses in the surrounding material. The amount of induced deformations and stresses is highly dependent on the nature of surrounding material as well as the depth of the excavation. The transition between the surface and underground structures are tunnel portals, at this junction the conditions can abruptly change causing several issues of instability as well as the stability of associated structures and adjacent slopes are also attached with tunnel portals. Furthermore, tunnel portal excavation becomes much more challenging when the encountered material is the soft ground of low shear strength such as alluvial deposits. Such material offers great resistance to any excavation as their properties are much closer to those of soil [1-4].

In order to enhance the stability of underground structure during construction and post-construction, always there exist two approaches either to increase tunnel support or to change tunnel excavation sequence. The later one is always given preference because of cost constraints and many other projects factors. Normally, the selection of a suitable excavation sequence can enable safe and stable excavation in any material [5-8]. Among various approaches of excavation, sequential excavation method (SEM) appropriately defines the sequences of excavation by considering the nature of surrounding material and size of structure opening. But the final selection of excavation sequence is highly dependent on the cost, safety, project conditions and project scheduling [9]. In addition to all these, technical factors such as; surrounding material properties, size and shape of the opening, regional geology and many to name more have proven themselves as a handful tools for the selection of an optimum excavation sequence [10].

This study focuses on the selection of an optimum excavation sequence for the safe and stable construction of a large diameter $(15.0 \mathrm{~m})$ hydropower tunnel portal in alluvial deposits. This tunnel portal has been constructed at a renowned hydropower project in the North-Eastern areas of Pakistan. At this particular project, large tunnel diameter excavation in the alluvial deposit was a great challenge. Moreover, the occurrences of a number of collapses in a tunnel of 11.0 $\mathrm{m}$ diameter excavated in alluvial deposit using heading and benching technique, clearly indicated the insufficiency and incompatibility of heading and benching. Therefore, it was necessary to re-design the excavation sequence for the tunnel portal construction of $11.0 \mathrm{~m}$ diameter. Thus, two new sequences of tunnel portal excavation were proposed which were analyzed in 2D using a Finite Element Method (FEM) program Phase 2D 8.0. There exit several numerical approaches such as Discrete Element Method (DEM) [11] and Discontinuous Deformation Analysis (DDA) [12]. FEM has been selected because of its simple modeling and it is easily available. These new excavation designs were proposed by considering project constraints such as cost, pre-defined tunnel support, available machinery and project schedule. Among these designs, one which showed minimum surface 
and inside portal displacement in FEM analysis to ensure maximum safety was selected and followed exactly in the same pattern at the construction site. Moreover, the post-construction safety was considered during the selection of this excavation sequence. Finally, the tunnel portal was constructed with the selection of an appropriate excavation design. Major contributions of this study are:

1. 2D FEM modelling of tunnel excavation in alluvial deposit of nonuniform nature.

2. Comparison of heading and benching, and sequential excavation sequence methods of tunnel excavation.

3. Selection of an appropriate excavation sequence to ensure maximum safety within the project constraints and pre-defined tunnel supports.

In the present study, Section 2 explains the case study along with the geotechnical properties of lithologies present at the construction site as well it summarizes the properties of encountered alluvial deposit. Moreover, it defines the alternative excavation sequences of tunnel portal. Section 3 describes the conditions of numerical modeling. Section 4 compares the principle stresses, total displacement and yielded elements for heading and benching, and sequential excavation methods. Section 5 emphasizes on the conclusions along with some discussion.

\section{CASE STUDY}

In recent years, Pakistan has focused on renewable energy resources, among those energy resources hydropower is a paramount energy provider. The case study hydropower project is a renowned under the construction project in the NorthEastern areas of Pakistan. Most of the underground structures at this particular project have been excavated in hard rock, nevertheless, initial $100 \mathrm{~m}$ of the headrace tunnel and associated tunnel portal were excavated in soft ground (alluvial deposit). This tunnel portal has a diameter of $15.0 \mathrm{~m}$ which reduces to $11.0 \mathrm{~m}$ of headrace tunnel. Larger diameter excavation in alluvial deposit imposed potentially instability threats, thus, it was a great challenges to ensure during construction and post-construction safety. The safety was ensured through the selection of an appropriate sequential excavation design. Present study aims at the selection of optimum excavation sequence of the tunnel portal in alluvial deposit to ensure construction and post construction safety. Therefore, a tunnel portal of 15.0 $\mathrm{m}$ diameter has been modelled and analyzed in $2 \mathrm{D}$ with various excavation designs and sequences.

The bed rocks in studied region lie in the lower western part of Himalayas and belong to Palaeocene to mid-Eocene geological age. Major lithological units are siltstone, sandstone, and mudstone while localized shale composed off fine particles of quartz, silt and clay, is also present up to some extent. Splintery and fractured nature of shales separates it from surrounding mudstone. Sandstone has been classified into two categories: SS1 and SS2 depending on its strength and colour. Sandstone (SS1) is mostly composed of fine to medium size particles of purple grey to greenish grey color, with the dominance of fines and high strength [13]. The bedding contact of this sandstone with contiguous lithologies is very sharp and abrupt. On the other hand, medium to strong sandstone (SS2) is mostly 
composed off reddish brown sand and silt particles. SS2, siltstone, and mudstone are hard to differentiate because they are pretty much similar in color, only the foremost distinction is the amount of fines, which increases from sandstone to mudstone. Among these three different rocks types, siltstone has an intermediate amount of fines while mudstone can be ranked highest for the utmost quantity of fine particles. Table 1 illustrates the encountered rock mass lithologies along with their geotechnical properties.

Table 1. Lithologies of rock masses and their properties at the study area.

\begin{tabular}{|c|c|c|c|c|c|c|c|c|}
\hline \multirow{2}{*}{$\begin{array}{l}\text { Sr. } \\
\text { No } \\
\text {. }\end{array}$} & \multirow[t]{2}{*}{ Lithology } & \multirow[t]{2}{*}{$\begin{array}{c}\text { Poison's } \\
\text { Ratio }\end{array}$} & UCS & $\begin{array}{l}\text { Young's } \\
\text { Modulus }\end{array}$ & Density & Cohesion & $\begin{array}{c}\text { Slake } \\
\text { Durability }\end{array}$ & \multirow{2}{*}{$\begin{array}{r}\text { Tensile } \\
\text { Strength }\end{array}$} \\
\hline & & & (MPa) & (GPa) & $\mathrm{Kg} / \mathrm{m}^{3}$ & $\mathrm{MPa}$ & $(\%)$ & \\
\hline 1 & SS1 & 0.27 & 86 & 58.1 & 2705 & 6.02 & 98.95 & 9.65 \\
\hline 2 & $\mathrm{SS} 2$ & 0.25 & 75 & 50 & 2719 & 5.961 & 97.9 & 13.11 \\
\hline 3 & Mudstone & 0.21 & 42 & 27.4 & 2766 & 5.87 & -- & -- \\
\hline 4 & Siltstone & 0.31 & 66 & 40.6 & 2766 & 8.91 & -- & -- \\
\hline 5 & Shale & 0.3 & 24.36 & 22.25 & 2726 & -- & -- & -- \\
\hline
\end{tabular}

The host material of headrace tunnel portal is an alluvial deposit of late Oligocene to early Miocene geological age. Site and laboratory investigations conducted on this alluvial deposit showed that it is a well compacted to well-cemented material. The main constituents are gravels, clay, and sand. The gravels are well graded and also rounded to well-rounded varying from few centimeter to $20 \mathrm{~cm}$, while, the sand and clay acts as matrix. However, contact between gravels and the filling material is sharp. Gravel or cobble gravel is appropriate terms for this alluvial deposit instead of term conglomerate. Boreholes drilled during preliminary investigations suggested that the only shallow water table and perched on bedrock is present. Therefore, it was a clear indication for dry to damp tunneling in this alluvial deposit. Anyhow, a slightly damped or minor inflow $(<1$ Liter/min) was observed during the portal construction. Geotechnical investigations classified this material as Well Graded Gravel with Sand and Clay (GW-GC), according to the Unified Soil Classification System (USGS).

Testing in actual field actual field conditions for such material has always been preferred over the scale testing because of the less sample disturbance and determination of accurate properties of materials. Some laboratory scale wet sieve analysis and hand sorting showed $70-75 \%$ cobbles or gravels, sand in a range of 5-15\% and fines with less than $10 \%$. Some other grading also indicated 11-12\% of fines. The angle of repose was found in the range of $40-45^{\circ}$, rather than showing it vertical or near vertical. Poison's ratio was found to be 0.25 . Before the commencement of portal construction, geotechnical properties such as bulk density, cohesion and friction angle were determined using Mohr-columnb elastoplastic model. The non-homogenousity of alluvial deposit showed brittle behavior. The regression line with best fitting all points of direct field shear tests gave cohesion (c) and friction angle of $143 \mathrm{kPa}$ and $39^{\circ}$, respectively. Afterward, comprehensive analysis of $80 \mathrm{~m}$ high slope, suggested designing tunnel with cohesion $=100 \mathrm{kPa}$ and friction angle $=38^{\circ}$. Alluvial deposit strength properties have been tabulated in Table 2 . 
Table 2. Classification and shear strength parameters of alluvial deposit at portal site.

\begin{tabular}{|c|c|c|c|c|c|c|c|c|c|}
\hline \multicolumn{6}{|c|}{ Classification parameters } & \multicolumn{4}{|c|}{ Shear strength parameters } \\
\hline \multirow{2}{*}{$\begin{array}{l}\text { Bulk } \\
\text { density } \\
\left(\mathrm{t} / \mathrm{m}^{3}\right)\end{array}$} & \multirow{2}{*}{$\begin{array}{c}\text { Dry } \\
\text { density } \\
(\mathrm{t} / \mathrm{m} 3)\end{array}$} & \multirow{2}{*}{$\begin{array}{c}\text { Moisture } \\
\text { content } \\
(\%)\end{array}$} & \multicolumn{3}{|c|}{ Atterberg Limits of fine } & \multicolumn{2}{|c|}{ Cohesion $(\mathrm{kPa})$} & \multicolumn{2}{|c|}{ Friction angle $\left({ }^{\circ}\right)$} \\
\hline & & & LI & PL & PI & Actual & Design & Actual & Design \\
\hline 2.33 & 2.24 & 6.9 & 23 & 16 & 7 & 143 & 100 & 39 & 38 \\
\hline
\end{tabular}

LI: Liquid limit, PL: Plastic limit, PI: Plasticity index

Barton's Q value system has been applied for the classification of existing sedimentary rock mass at the project site, because of its unsurpassed dealing with all parameters of joints and parameters related to sedimentary rocks. Although, it serves best for sedimentary rocks, it is not only hard but also impossible to classify non uniform alluvial deposit using Barton's $Q$ value classification system.

The main reason behind it is the geotechnical properties of alluvial deposit which are in between those of rocks and soils. Anyhow, support equivalent to Barton Q-5 along with some addition of $4.5 \mathrm{~m}$ long grout pipes (dia. $=105 \mathrm{~mm}$ ) at center-to-center distance of 0.5 $\mathrm{m}$ extending towards each side of portal has been considered for computer modelling. Afterwards, these grouted pipes were neglected during the portal construction, as the less stand-up time of alluvial deposit resulted in collapse or even stacking of drilling rod.

The average recommended support for Barton Q5 is fibre reinforced shotcrete (12-15 $\mathrm{cm})$ build up progressively. Three cord lattice girders $[\phi=32 \mathrm{~mm}, \phi=22 \mathrm{~mm}$ (2)], along with the installation of wire mesh $(6 \times 100 \times 100 \mathrm{~mm})$. Rock bolts $(\phi=25 \mathrm{~mm}, \mathrm{~L}=1.2 \mathrm{~m} @ 1 \mathrm{~m})$ for restricting the longitudinal movement of lattice girders.

During the construction of portal, the excavation sequence has been followed in exactly same manner. For each stage, face advance was not much more than $0.6-$ to $0.7 \mathrm{~m}$, just to adjust two lattice girders in same excavation. Initially, a thin layer (approx. 4-5 cm) of fiber reinforced shotcrete covered the freshly exposed alluvial deposit surface. This shotcrete layer helped to increase stand-up time of excavation and made it easy for the installation of lattice girders and interconnected wire mesh. The installation of lattice girders and wire mesh has been followed by the installation of rock bolts to fix longitudinal movement of lattice girders. These rock bolts fixed the longitudinal direction of lattice girders. Lastly, shotcrete plain $(12-15 \mathrm{~cm})$ progressively build up has been applied to cover the installed lattice girders. The excavation and subsequent support applications for Stage 1 have been shown in Fig. 1 while all other excavation stages followed same support installation sequence. 


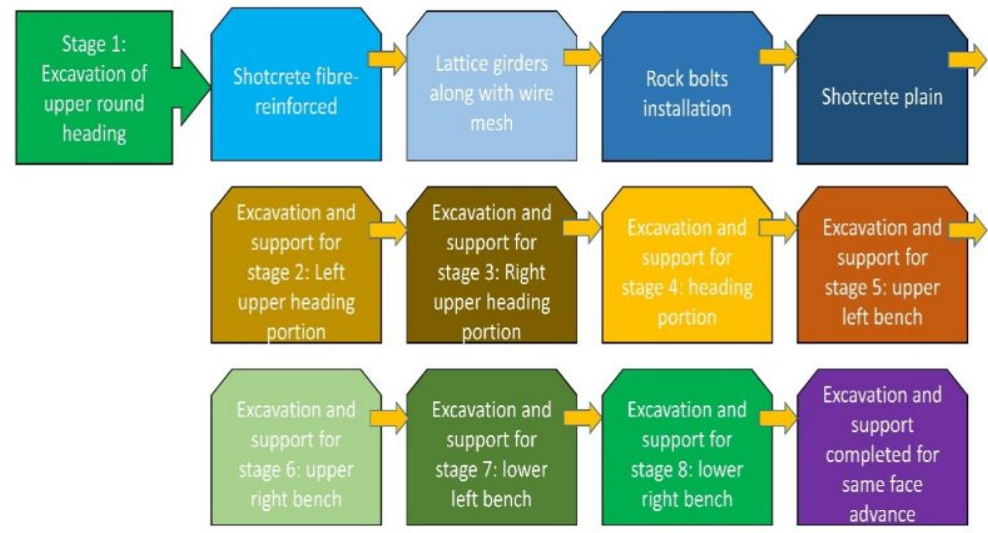

Fig. 1. Stage wise excavation and support sequence of tunnel portal.

The construction sequence of the portal in alluvial deposit was determined with the combination of geotechnical investigation and geological engineering. Fig. 2 represents three different SEM designs. First excavation design Fig. 2 (a) shows the division of complete portal only in heading and benching of height $6.6 \mathrm{~m}$ and $8.4 \mathrm{~m}$, respectively. However, by considering the previous experience of slope cutting and tunnel excavation in same material at the same site, it was not possible to excavate portal only in heading and benching. For numerical modeling, another portal excavation design was proposed which divided the entire portal face into four segments, shown in Fig. 2 (b). Third design, divided the complete portal face into eight panels. The method of face excavation in this design was somehow a combination of heading and benching, and sequential excavation method. Fig. 3 (a) describes the sequence of this design. Further, division of portal face was not practically possible due to machinery constraints. Anyhow, it was necessary, to investigate second and third designs in terms of stability and safety, before the execution. Fig. 3 (b) represents the sequence of portal excavation along with activities for third excavation design.

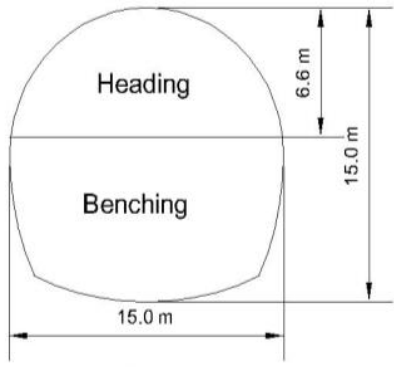

A

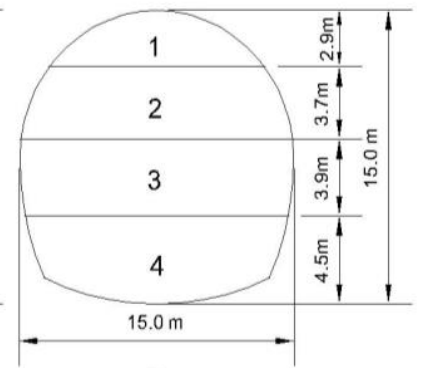

B

Fig. 2. Excavation designs of $15.0 \mathrm{~m}$ diameter tunnel portal using heading and benching method (a) Two stages excavation, (b) four stages excavation design. 


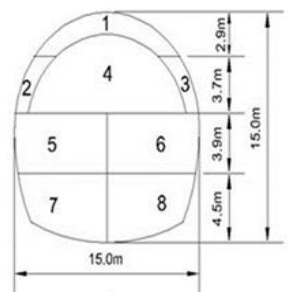

(a)

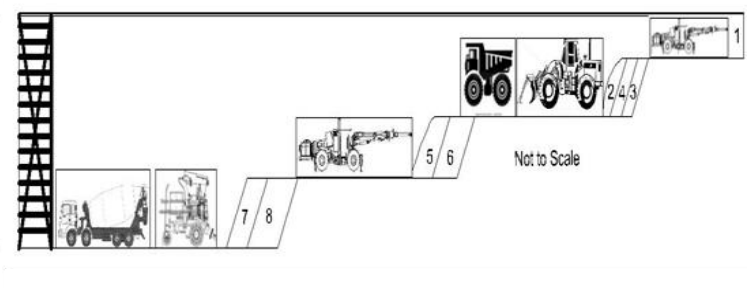

(b)

Fig. 3. Proposed and finally selected sequential excavation design (SEM) for the construction of 15.0 m diameter tunnel portal.

\section{NUMERICAL MODELLING}

The numerical model of the tunnel was constructed using the well-known finite element code Phase 2 by Roc-science. It is a powerful 2D finite element program for soil and rock applications. Phase 2 can be used for a wide range of engineering projects and includes excavation design, slope stability, groundwater seepage, probabilistic analysis, consolidation, and dynamic analysis capabilities. The tunnel two dimensional crosssectional area file was imported in the Phase 2 software and tunnel area was constructed. This was followed by construction of model boundaries. The boundaries are kept at a distance of three times the dimensions of the tunnel portal except the top boundary which is free surface. The option of infinite elements was used at the model boundaries which assume that the rock material is continuing in plane. This option enables a user to construct a smaller model while having no or little effects on the model results. In the next stage, material properties were defined for rock material as shown in Table 1 and 2. The in-situ stresses were estimated based on the work of Arjang [14-16]. The estimated stresses are shown in Table 3.

Mesh sensitivity analysis was also performed to optimize the number of elements. This is achieved by constructing a $5.5 \mathrm{~m}$ by $5.5 \mathrm{~m}$ opening at the center of the model and observing the convergence for different mesh densities. It was observed that some mesh densities yield in to consistent results. Any of these mesh densities can be selected for consistency and precision. In this work mesh density with a total number of 20,500 elements was selected after the mesh sensitivity analysis. The finite element mesh is shown in Fig. 4.

Table 3. In-situ stress parameters.

\begin{tabular}{ll}
\hline Parameter & Value \\
\hline Unit weight, $\gamma(\mathrm{kN} / \mathrm{m})$ & 2.71 \\
Depth, $\mathrm{H}(\mathrm{m})$ & 15 \\
Horizontal to vertical stress ratio, $\mathrm{K}$ & 1.3 \\
Vertical stress, $\sigma_{\mathrm{v}}(\mathrm{kN})$ & 13.55 \\
Horizontal stress, $\sigma_{\mathrm{h}}(\mathrm{kN})$ & 17.62 \\
\hline
\end{tabular}




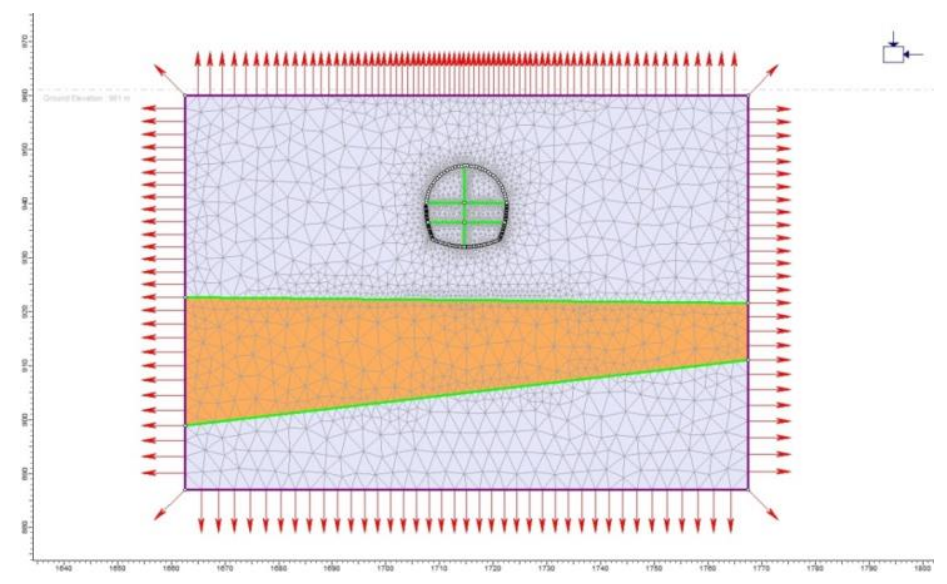

Fig. 4. Numerical model with boundary conditions.

\section{RESULTS AND DISCUSSION}

Tunnel portal construction methods including top heading and benching, and sequential excavation method, described in Section 3 are compared for stability. The two methods are simulated using the Phase 2 software. The support system including the liners (shotcrete and lattice girder) and rock bolt (dowels) support system employed by the case study project are also simulated in the later part. The results of the numerical model of the two construction methods are compared with respect to major principal stress, total displacement and yielded elements. The results are shown after complete extraction for the heading and benching method and sequential excavation method. The results for two sequences are simulated initially with no support. Later on support system is installed and the results are compared. The results of major principal stress for heading and benching method and sequential excavation method with no supports installed are shown in Fig. 5. As can be seen there is almost no difference in stress magnitude around the tunnel portal, however the yielded elements have decreased significantly. Notably, the maximum stress level near the heading is around $1.25 \mathrm{MPa}$, which is very low and is actually not enough to provide the clamping force necessary to resist unraveling of blocks. The results of total displacement for the two methods are shown in Fig. 6. The vectors of displacement can also be seen in the Fig. 6 . The maximum displacement of $2.5 \mathrm{~cm}$ can be observed at the bottom of the tunnel. The crown of the tunnel has moved up to around $0.825 \mathrm{~mm}$. It can be seen that the heading and benching method shows a greater displaced area around the tunnel. The results of two methods are also compared in terms of yielded area around the excavation; Fig. 7 depicts these results. It can be seen that there is a huge yielded area in floor and side walls for simulated heading and benching method. The floor of the excavation is also disturbed. The simulated SEM also shows yielding in the side walls and crown, with relatively lesser yielding in the floor. 


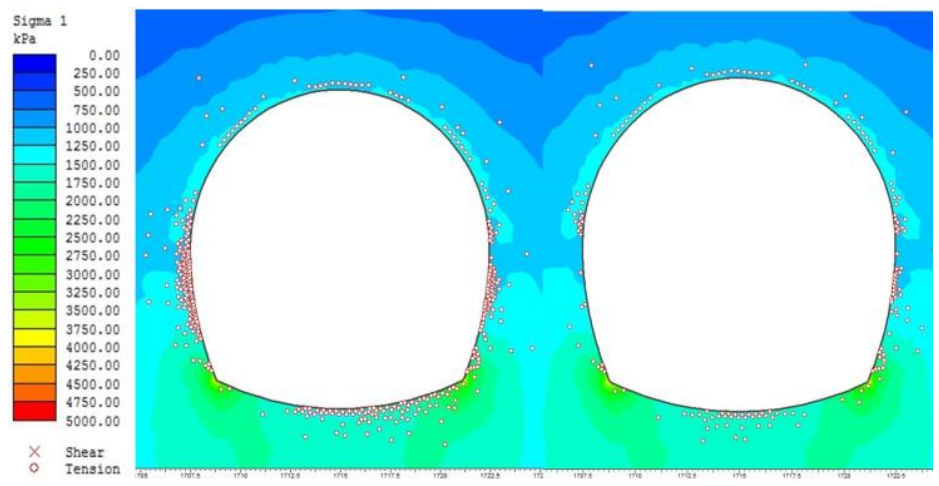

(a)

(b)

Fig. 5. Major Principal Stress contours with no support installed, (a) heading and benching, and (b) sequential excavation method.

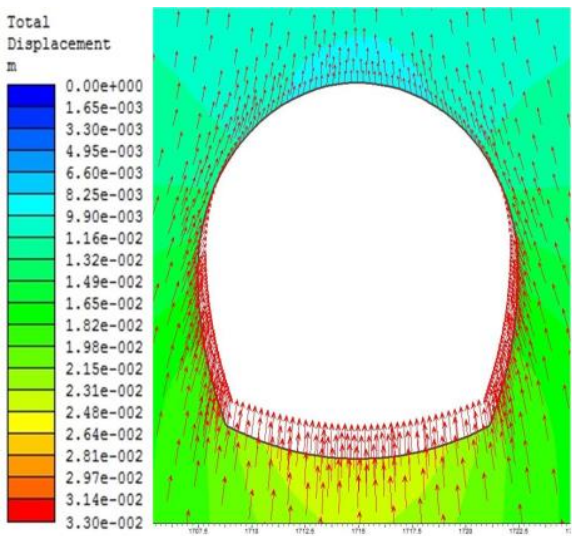

(a)

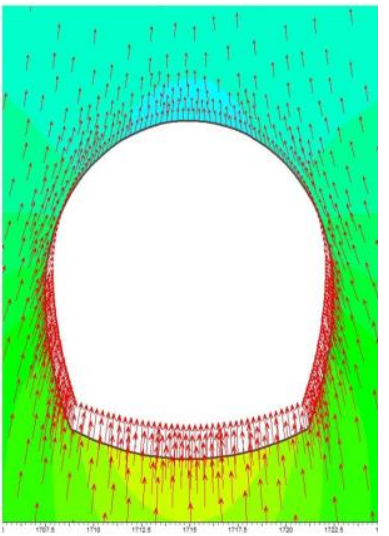

(b)

Fig. 6. Contours of total displacement with vectors, and without tunnel supports, (a) heading and benching, and (b) sequential excavation method. 


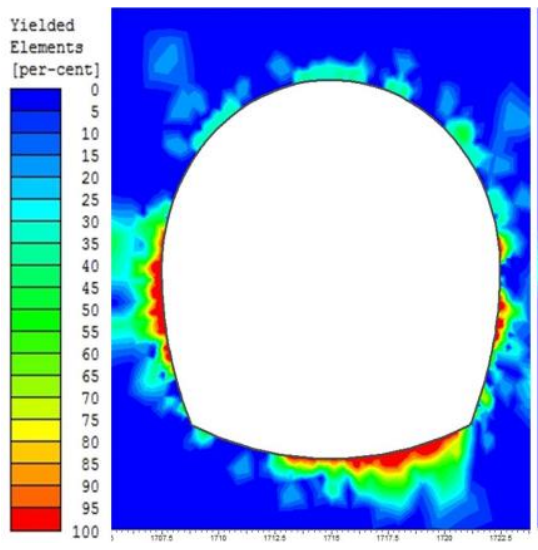

(a)

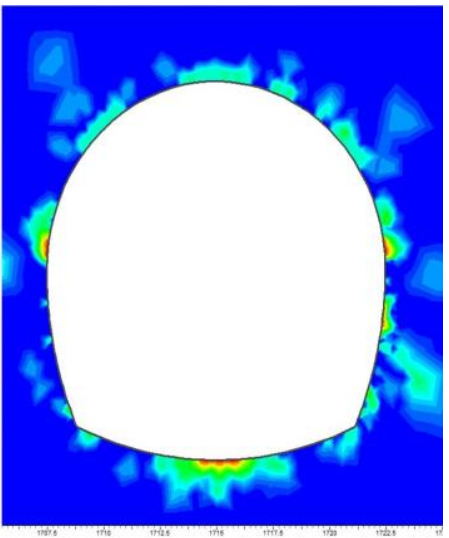

(b)

Fig. 7. Contours of yielded elements when no supports was considered (a) heading and benching, and (b) sequential excavation method.

In the next analysis support system is installed for both the methods while following the excavation and support system installation sequence of case study project. In the first step the excavation is made followed by installation of liners and dowels. The excavation and support installation sequence is followed for both the methods. The results of major principal stress are shown in Fig. 8. It can be seen that the stress concentration around Fig. 8 (a) is higher $(1.2$ to $3 \mathrm{MPa})$ than that of Fig. 8 (b) $(0.8 \mathrm{MPa}$ to $2.2 \mathrm{MPa})$. Once again the major principal stress is on the lower side. Similarly the yield zones are greater in number for heading and benching method. Fig. 9 (a) and (b) show the results of total displacement for both the construction methods. It can be observed the total displacement for heading and benching method is around $2.4 \mathrm{~cm}$ in floor and $0.5 \mathrm{~cm}$ in the crown. The total displacement for the SEM is around $1.8 \mathrm{~cm}$ in the floor and $1 \mathrm{~cm}$ for the crown.

Fig. 10 represents the contours of yielded volume for the two construction methods simulated with supports installed. As can be seen big yielded volume can be observed for the heading and benching method compared to SEM. No support has been yielded in this analysis. The results found from this analysis can be correlated with the field observations.

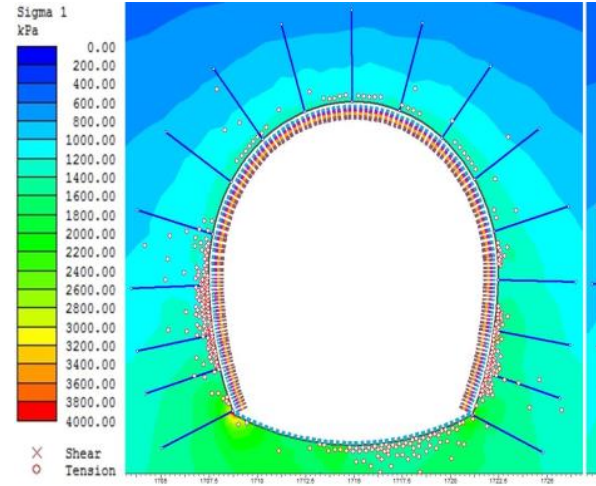

(a)

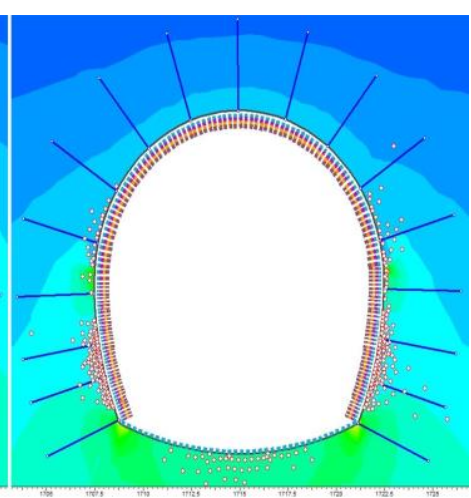

(b)

Fig. 8. Contours of major principal stress with support system installed (a) heading and benching and (b) sequential excavation method. 


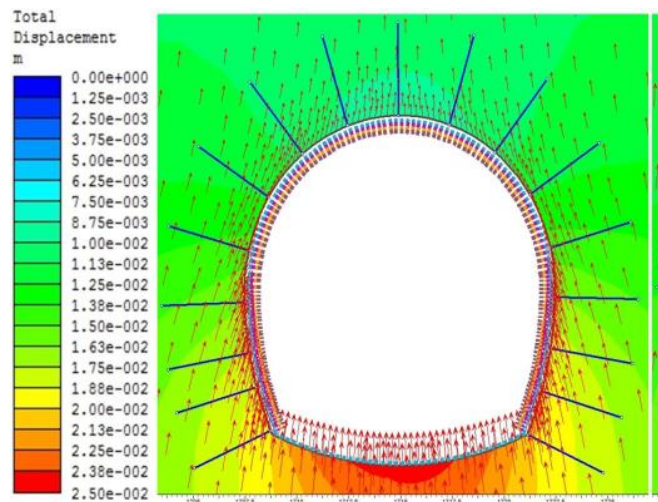

(a)

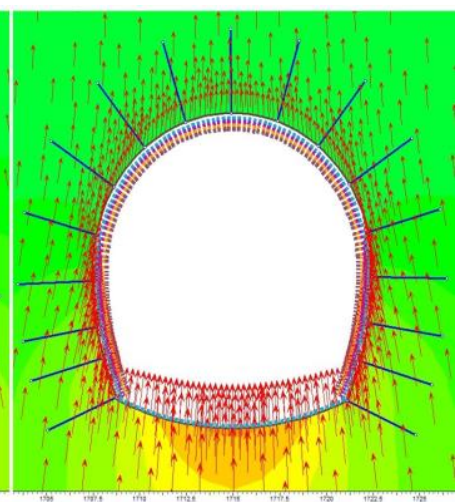

(b)

Fig. 9. Contours of total displacement with support system installed (a) heading and benching, and (b) sequential excavation method.

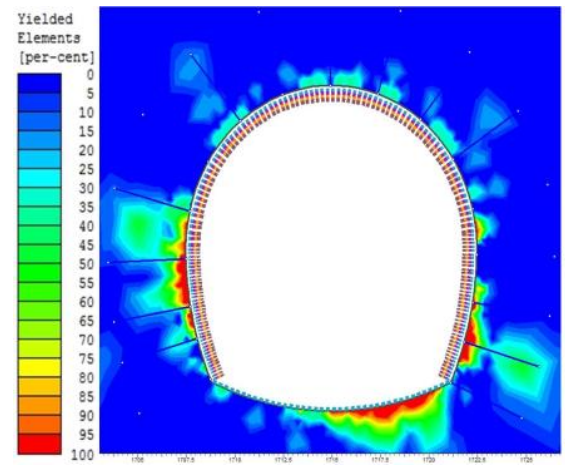

(a)

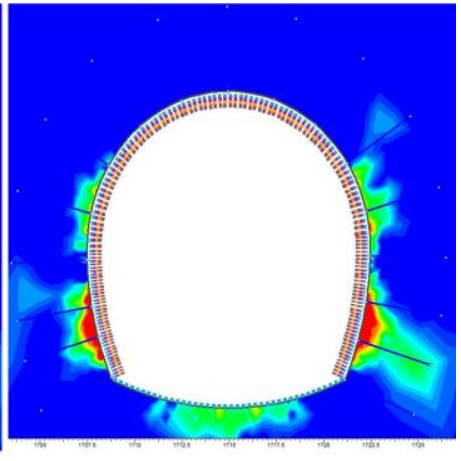

(b)

Fig. 10. Contours of yielded volume with support system installed (a) heading and benching, and (b) sequential excavation method.

The axial stress on all the bolts is calculated by Phase 2 software and is shown in Fig. 11. It was found that the maximum stress is $17.5 \mathrm{kPa}$ and $37 \mathrm{kPa}$ for SEM and heading and benching method, respectively. The minimum axial stress in the bolts is $6 \mathrm{kPa}$ for SEM and $5 \mathrm{kPa}$ for heading and benching methods. The radial stress on liners is also computed using Phase 2 and is shown in Fig. 12. It was found that the maximum stress is $2 \mathrm{MPa}$ and 1.3 MPa for heading and benching, and SEM respectively. The minimum stress is around 3.75 $\mathrm{MPa}$ and 4.30 MPa for heading and benching, and SEM, respectively. 


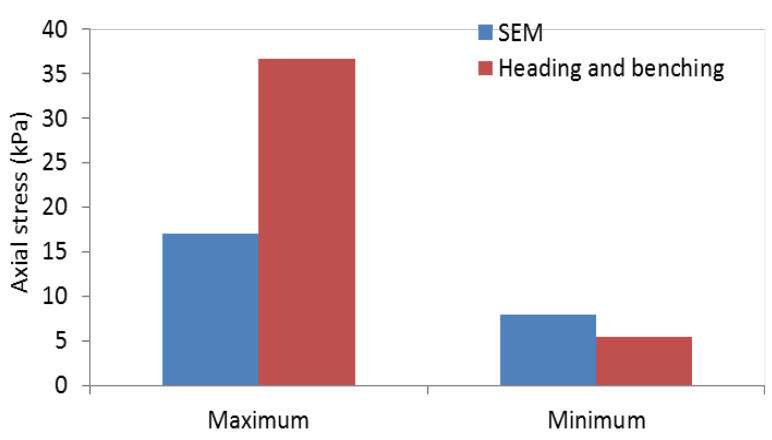

Fig. 11. Axial stress on dowels due to yielding around the tunnel portal.

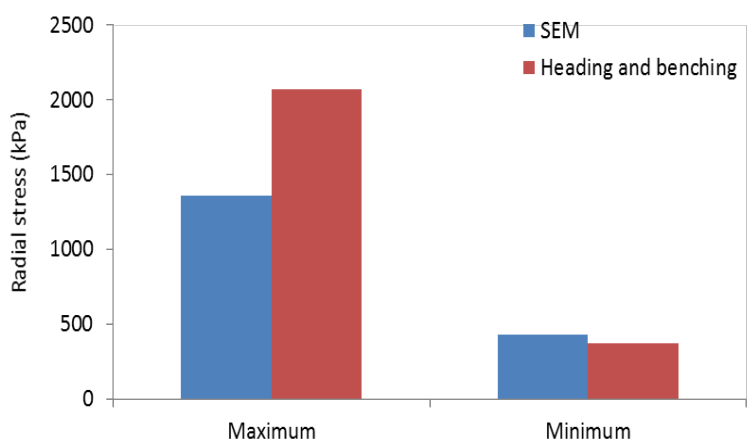

Fig. 12. Radial stress on the combined liners due to yielding around tunnel portal.

The results of the tunnel portal analysis in alluvium show promising results that can also be compared with field observations to achieve meaningful predictions. The limitations of this study include the lack of field data in terms of in-situ stress and a three dimensional numerical modelling code.

\section{CONCLUSION}

Portal construction in soft rock is one of the most challenging tasks in construction of tunnels. Soft rocks and in-situ stresses underground dictates the stability of excavations. A proper excavation sequence and support installation can mitigate tunnel portal failures in soft rock. Using FEM codes, it is demonstrated that a proper tunnel design and supports can be selected with great success. Two out of three proposed designs are studied with and without the proposed support system using Phase 2. It is found that the sequential excavation design with the proposed support system is more suitable than the heading and benching method. The results are shown in terms of maximum stresses around the tunnel, total displacement and yielded volumes. In the later part the maximum axial stress on bolts and liners are also computed using the numerical models. These results can be calibrated and validated using field measurements to predict ground failures in tunnel portal and design can be altered accordingly. 


\section{REFERENCES}

1. Lai, K., Geotechnical properties of colluvial and alluvial deposits in Hong Kong. The, 2011. 5: p. 735-744.

2. Zhang, G.-H., Y.-Y. Jiao, and H. Wang, Outstanding issues in excavation of deep and long rock tunnels: a case study. Canadian Geotechnical Journal, 2014. 51(9): p. 984-994.

3. Qiu, S., et al., Estimation of rockburst wall-rock velocity invoked by slab flexure sources in deep tunnels. Canadian Geotechnical Journal, 2014. 51(5): p. 520-539.

4. Zhou, H., et al., Analysis of mechanical behavior of soft rocks and stability control in deep tunnels. Journal of Rock Mechanics and Geotechnical Engineering, 2014. 6(3): p. 219-226.

5. Sharifzadeh, M., R. Daraei, and M.S. Broojerd, Design of sequential excavation tunneling in weak rocks through findings obtained from displacements based back analysis. Tunnelling and Underground Space Technology, 2012. 28: p. 10-17.

6. Koçkar, M.K. and H. Akgün, Tunnel and portal stability assessment in weak rock, in Underground Space Use: Analysis of the Past and Lessons for the Future E. Solak, Editor. 2005, 2005 Taylor \& Francis Group, London, ISBN 0415374529.

7. Yasitli, N.E., Numerical modeling of surface settlements at the transition zone excavated by New Austrian Tunneling Method and Umbrella Arch Method in weak rock. Arabian journal of geosciences, 2013. 6(7): p. 26992708.

8. Zhang, G., Y. Jiao, and H. Wang, Outstanding issues in excavation of deep and long rock tunnel: a case study. Canadian Geotechnial Journal, 2014.

9. Hoek, E., BIG TUNNELS IN BAD ROCK. Journal of Geotechnical \& Geoenvironmental Engineering, 2001. 127(9): p. 726.

10. $\mathrm{Yu}, \mathrm{C}$. and J. Chern, Expert system for D\&B tunnel construction. Underground Space The 4th Dimension of Metropolises, London, England, 2007.

11. Jing, L. and O. Stephansson, 1-Introduction. Developments in geotechnical engineering, 2007. 85: p. 1-21.

12. Wu, J., J. Chen, and D. Lee. Investigation of the Initiation of the Hsien-dushan Rock Avalanche in Taiwan Using DDA. in 48th US Rock Mechanics/Geomechanics Symposium. 2014. American Rock Mechanics Association.

13. Burg, J., et al., Infra-arc mantle-crust transition and intra-arc mantle diapirs in the Kohistan Complex (Pakistani Himalaya): petro-structural evidence. TERRA NOVA-OXFORD-, 1998. 10: p. 74-80.

14. Arjang, B., Premining ground stresses at the Bousquet/Dumagami mines, Cadillac, Quebec. CANMET, Energy, Mines and Resources Canada, Div Report MRL 88-132 (TR), 1988. 
15. Sheory, P.R., A theory for in situ stresses in isotropic and transversely isotropic rock. Int. J. Rock Mech. Min. Sci. \& Geomechanics Abstracts, 1994. 31(1): p. 23-34.

16. Brown, E.T. and E. Hoek, Trends in relationships between measured rock in situ stresses and depth. Int. J. Rock Mech. Min. Sci. \& Geomech. Abstracts, 1978. 15: p. 211-215. 